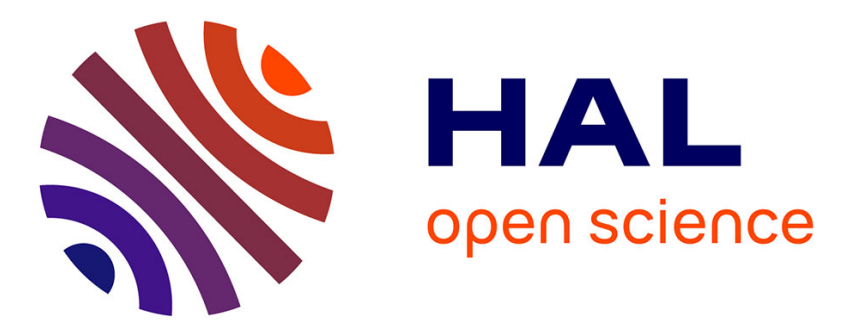

\title{
Ribosomal RNA degradation induced by the bacterial RNA polymerase inhibitor rifampicin
}

\author{
Lina Hamouche, Leonora Poljak, Agamemnon J. Carpousis
}

\section{To cite this version:}

Lina Hamouche, Leonora Poljak, Agamemnon J. Carpousis. Ribosomal RNA degradation induced by the bacterial RNA polymerase inhibitor rifampicin. RNA, 2021, 27 (8), pp.946-958. 10.1261/rna.078776.121 . hal-03340144

\section{HAL Id: hal-03340144 \\ https://hal.inrae.fr/hal-03340144}

Submitted on 10 Sep 2021

HAL is a multi-disciplinary open access archive for the deposit and dissemination of scientific research documents, whether they are published or not. The documents may come from teaching and research institutions in France or abroad, or from public or private research centers.
L'archive ouverte pluridisciplinaire HAL, est destinée au dépôt et à la diffusion de documents scientifiques de niveau recherche, publiés ou non, émanant des établissements d'enseignement et de recherche français ou étrangers, des laboratoires publics ou privés.

\section{(ㄷ)(1) $\$$}

Distributed under a Creative Commons Attribution - NonCommerciall 4.0 International 


\title{
Ribosomal RNA degradation induced by the bacterial RNA polymerase inhibitor rifampicin
}

\author{
LINA HAMOUCHE, ${ }^{1}$ LEONORA POLJAK, ${ }^{1}$ and AGAMEMNON J. CARPOUSIS ${ }^{1,2}$ \\ ${ }^{1}$ LMGM, Université de Toulouse, CNRS, UPS, CBI, 31062 Toulouse, France \\ ${ }^{2}$ TBI, Université de Toulouse, CNRS, INRAE, INSA, 31062 Toulouse, France
}

\begin{abstract}
Rifampicin, a broad-spectrum antibiotic, inhibits bacterial RNA polymerase. Here we show that rifampicin treatment of Escherichia coli results in a $50 \%$ decrease in cell size due to a terminal cell division. This decrease is a consequence of inhibition of transcription as evidenced by an isogenic rifampicin-resistant strain. There is also a $50 \%$ decrease in total RNA due mostly to a $90 \%$ decrease in $23 \mathrm{~S}$ and $16 \mathrm{~S}$ rRNA levels. Control experiments showed this decrease is not an artifact of our RNA purification protocol and therefore due to degradation in vivo. Since chromosome replication continues after rifampicin treatment, ribonucleotides from rRNA degradation could be recycled for DNA synthesis. Rifampicin-induced rRNA degradation occurs under different growth conditions and in different strain backgrounds. However, rRNA degradation is never complete, thus permitting the reinitiation of growth after removal of rifampicin. The orderly shutdown of growth under conditions where the induction of stress genes is blocked by rifampicin is noteworthy. Inhibition of protein synthesis by chloramphenicol resulted in a partial decrease in 23S and 16S rRNA levels whereas kasugamycin treatment had no effect. Analysis of temperature-sensitive mutant strains implicate RNase E, PNPase, and RNase R in rifampicininduced rRNA degradation. We cannot distinguish between a direct role for RNase $E$ in rRNA degradation versus an indirect role involving a slowdown of mRNA degradation. Since mRNA and rRNA appear to be degraded by the same ribonucleases, competition by rRNA is likely to result in slower mRNA degradation rates in the presence of rifampicin than under normal growth conditions.
\end{abstract}

Keywords: cell size; mRNA degradation; rifampicin; ribosomal RNA degradation; RNase E; PNPase; RNase R

\section{INTRODUCTION}

RNA is a versatile polynucleotide because of its capacity to form a variety of secondary and tertiary structures (Miao and Westhof 2017). The core translational machinery of life on earth is RNA-based. Ribosomal RNA (rRNA) and transfer RNA (tRNA) mediate decoding and peptidyl transferase activities (Moore and Steitz 2011). Ribosomal RNA and tRNA are highly structured and compact molecules, and interactions with ribosomal proteins, mRNA and enzymes involved in translation contribute to their stability. However, pathways for the degradation of rRNA and tRNA, which eliminate defective molecules and scavenge ribonucleotides during starvation, have been described in E. coli (Cheng and Deutscher 2003; Deutscher 2009; Zundel et al. 2009; Svenningsen et al. 2017; Kimura and Waldor 2019; Fessler et al. 2020). Inactive 30 S and 50 S ribosomal subunits have exposed RNA surfaces, normally buried in the active $70 \mathrm{~S}$ ribosome, that are targeted for

Corresponding author: agamemnon.carpousis@univ-tlse3.fr Article is online at http://www.rnajournal.org/cgi/doi/10.1261/rna. 078776.121. Freely available online through the RNA Open Access option. cleavages that initiate the degradation of $23 \mathrm{~S}$ and $16 \mathrm{~S}$ rRNA (Basturea et al. 2011; Sulthana et al. 2016). The multienzyme RNA degradosome and the 3'-exo-ribonuclease RNase $R$, which are involved in these processes, have RNA unwinding activities that facilitate the degradation of structured RNA (Py et al. 1996; Vanzo et al. 1998; Carpousis et al. 1999; Cheng and Deutscher 2005).

Messenger RNA ( $m R N A$ ) is the molecule that carries protein sequence information. Unlike rRNA and tRNA, the coding regions of $E$. coli mRNA tend to be unstructured and there is a genome-wide correlation between lack of structure and translation efficiency (Burkhardt et al. 2017). Messenger RNA is unstable. In E. coli, mRNA half-lives average $\sim 3$ min, which contrasts with cell doubling times ranging from 20 min to greater than $1 \mathrm{~h}$ depending on growth conditions (Bernstein et al. 2004; Esquerre et al. 2014; Chen et al. 2015; Moffitt et al. 2016; Laguerre et al. 2018). Messenger RNA instability is an economical way to ensure

(C) 2021 Hamouche et al. This article, published in RNA, is available under a Creative Commons License (Attribution-NonCommercial 4.0 International), as described at http://creativecommons.org/licenses/ by-nc/4.0/. 
that protein synthesis rapidly responds to the reprogramming of transcription in response to changes in growth conditions and stress (Perez-Ortin et al. 2019). Furthermore, mRNA degradation "shapes" the transcriptome since the level of an mRNA coding sequence is a function of both its rate of synthesis and its rate of degradation (Belasco 2017; Chao et al. 2017; Dar and Sorek 2018).

Rifampicin, a potent broad-spectrum antibiotic, is a frontline drug in the treatment of difficult to cure infections such as tuberculosis and leprosy (Alifano et al. 2015). In addition to its medical importance, rifampicin has routinely been used to measure mRNA stability. Rifampicin inhibits transcription of DNA by bacterial RNA polymerase (Campbell et al. 2001). Messenger RNA degradation rates are determined by measuring levels as a function of time after inhibition of transcription by rifampicin (Bernstein et al. 2004; Esquerre et al. 2014; Chen et al. 2015; Moffitt et al. 2016; Laguerre et al. 2018). Since mRNA is unstable, it represents only a small proportion of total RNA, which is composed mostly of rRNA and tRNA (Perez-Ortin et al. 2019). Therefore, it has generally been assumed that total RNA levels are constant after the inhibition of transcription by rifampicin. Here, we report that rifampicin treatment results in a $50 \%$ decrease in total RNA level due to the degradation of $23 S$ and $16 S$ rRNA. Rifampicin-induced rRNA degradation occurs under different growth conditions and in different strain backgrounds. RNase $E$, PNPase and RNase R participate in this degradation. The implications of rifampicin-induced rRNA degradation for measurements of mRNA stability are discussed.

\section{RESULTS}

\section{Cell size decreases after rifampicin treatment}

During work on the localization and dynamics of the RNA degradosome of $E$. coli using wide field microscopy, we saw a striking effect of rifampicin on cell size (Fig. 1A). Pre-

A
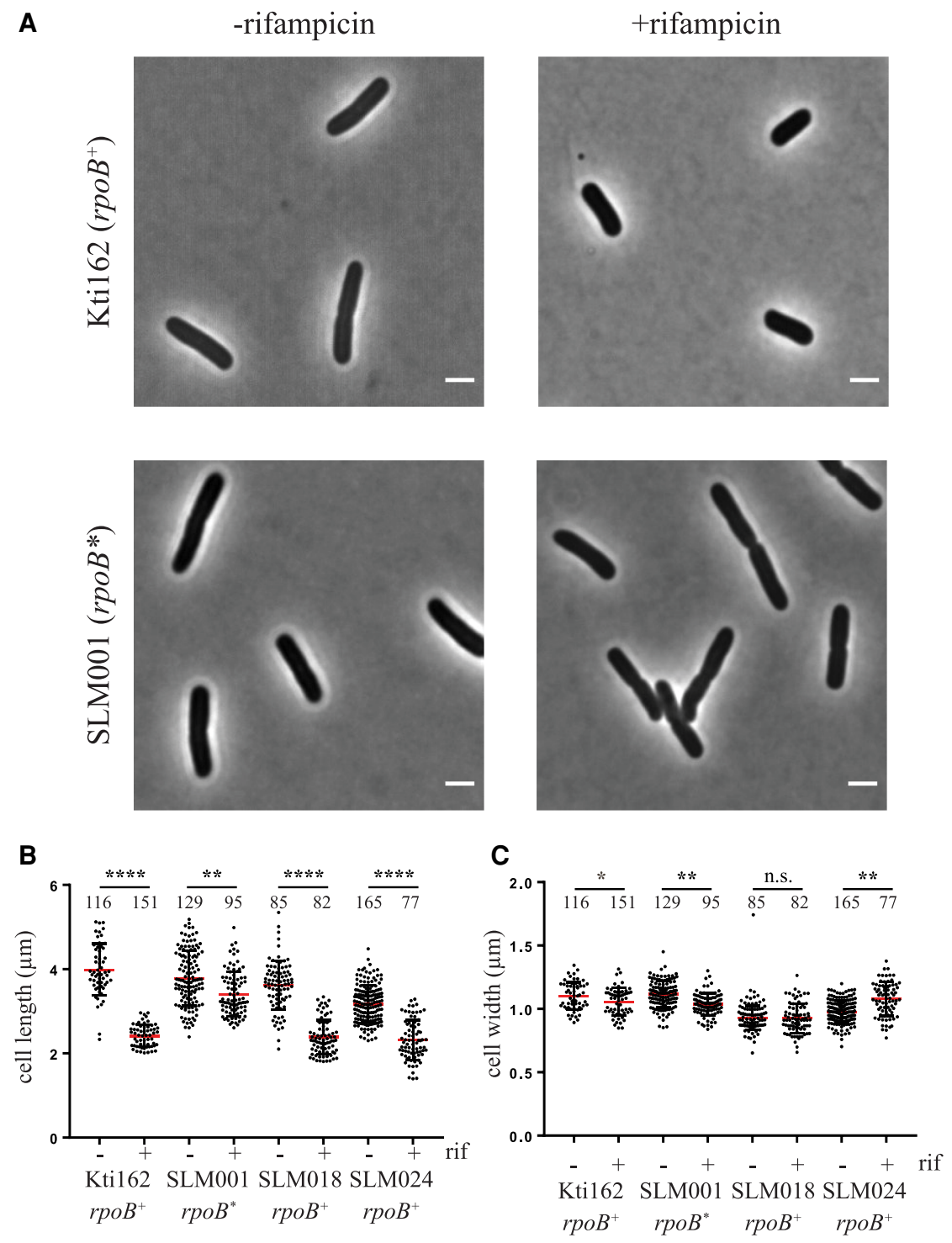

FIGURE 1. Cell dimensions. The Kti162 strain expressing RNase E-mCherry, SLM018 strain expressing PNPase-msfGFP, SLM024 strain expressing RhIB-msfGFP, and the isogenic rifampicin resistant strain $\mathrm{SLM001}$ were grown to $\mathrm{OD}_{600}=0.5$ in $\mathrm{LB}$ at $37^{\circ} \mathrm{C}$. (A) Phase contrast images before and $30 \mathrm{~min}$ after adding rifampicin $(150 \mu \mathrm{g} / \mathrm{mL})$. The bar in the lower right corner of each micrograph indicates scale $(2 \mu \mathrm{m})$. $(B, C)$ Scatter plots of cell length $(B)$ and width $(C)$. Since the results of two independent experiments were the same, the data were pooled. The number of cells that were measured are indicated at the top of the distribution profile. Statistical significance of the difference between untreated and rifampicin treated cells was calculated using the nonparametric Mann-Whitney test: $\left({ }^{* * * *}\right) P<0.0001 ;\left({ }^{* * *}\right) 0.0001<P<$ $0.001 ;\left(^{* *}\right) 0.001<P<0.01 ;\left(^{*}\right) 0.01<P<0.05 ;$ n.s. $=P>0.05$.

vious flow cytometry measurements showed that rifampicin treatment reduces cells size (Skarstad et al. 1986). Here, cell dimensions were quantified by direct measurement of 80 to 160 live cells (Fig. 1B,C). The length of the Kti162, SLM018, and SLM024 cells $30 \mathrm{~min}$ after rifampicin addition was $\sim 60 \%$ compared to untreated cells with strong statistical support for this size reduction $(P<0.0001)$. The effect on cell width is negligible. These 
strains, which express variants of RNA degradosome components tagged with msfGFP or mCherry, are derivatives of the wild-type E. coli K12 strain NCM3416.

As a control, we measured cell dimensions in a rifampicin resistant strain (Fig. 1B,C). SLM001, which is isogeneic to Kti162, has an rpoB(D516Y) mutation resulting in rifampicin resistant RNA polymerase (Campbell et al. 2001; Alifano et al. 2015). After rifampicin treatment, SLM001 cell length was $\sim 90 \%$ of the untreated control (Fig. 1B). Since the SLM001 strain continues to grow in the presence of rifampicin, the small decrease in length is likely due to a slowdown in growth as cells exit exponential growth phase (Akerlund et al. 1995). The SLM001 control shows that the decrease in cell size results from the inhibition of transcription by rifampicin. Since E. coli cell shape can be modeled as a cylinder with hemispherical caps, a decrease in cell length of $60 \%$ results in a $50 \%$ reduction in cell size. This result suggests that cells undergo a terminal reductive cell division after growth is arrested by rifampicin.

\section{RNA levels decrease after rifampicin treatment}

During the isolation of RNA from rifampicin treated cells, we noticed a decrease in yield per $\mathrm{mL}$ of culture $\sim 10 \mathrm{~min}$ after addition of the drug. This was unexpected since mRNA, which is unstable, is only a small proportion of total RNA. Figure 2A shows the quantification of the levels of total RNA from three biological replicates of rifampicin treated cells. As these cultures were growing exponentially, total RNA levels increase for several minutes after rifampicin addition due to a lag in inhibition of transcription. To avoid the bias that would result from normalization to total RNA levels, RNA yield was normalized per $\mathrm{mL}$ of culture. Since rifampicin is added at $\mathrm{OD}_{600}=0.50$, the mass of cells
A

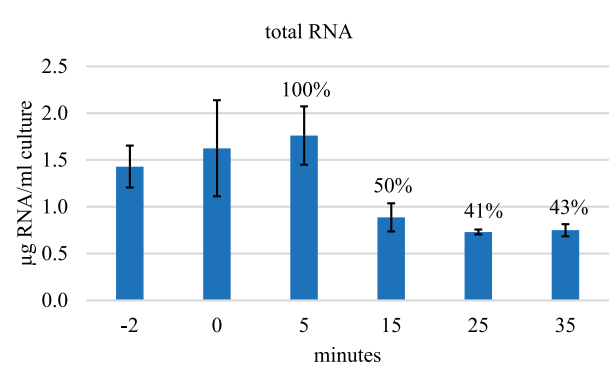

C

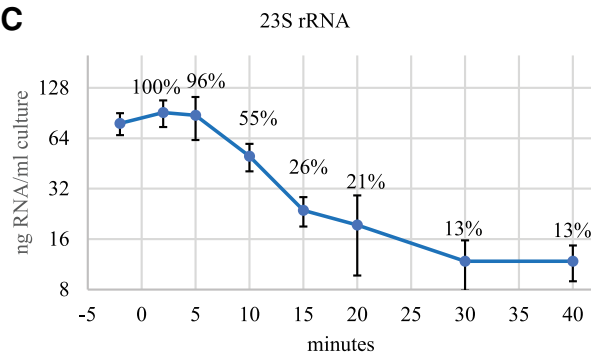

E

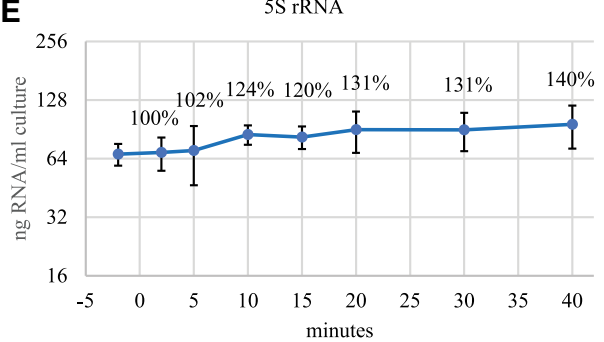

B

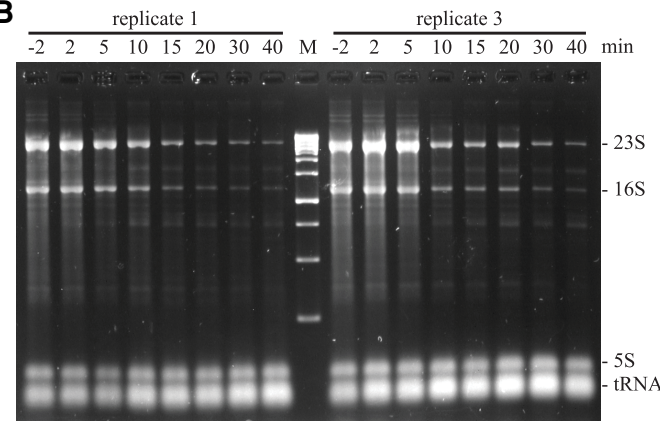

D

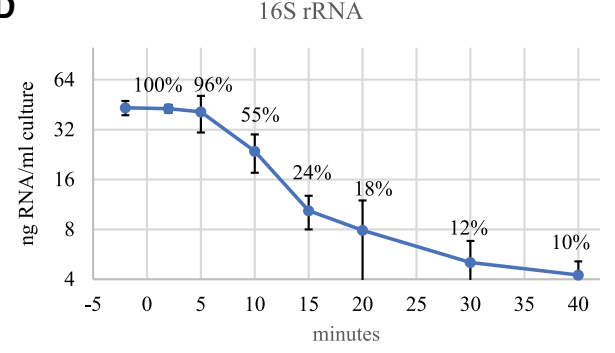

$\mathbf{F}$

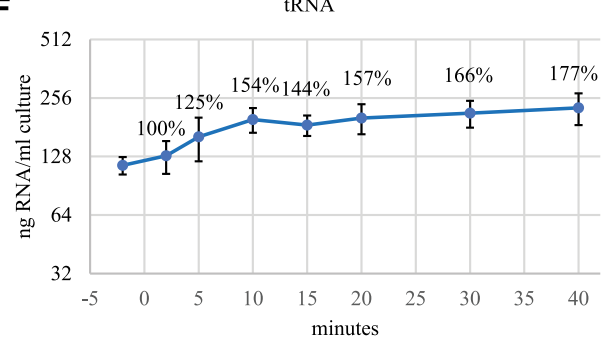

FIGURE 2. RNA levels after rifampicin treatment. The Kti162 strain was grown in $L B$ at $37^{\circ} \mathrm{C}$ to $\mathrm{OD}_{600}=0.5$ and then treated with rifampicin $(150$ $\mu \mathrm{g} / \mathrm{mL}$ ). (A) Total RNA. The 0 min time point was taken immediately after the addition of rifampicin. RNA was extracted from equal volumes of culture. Quantities are expressed as micrograms of RNA per $\mathrm{mL}$ of culture. The graph shows the average and standard deviation of three biological replicates. Percentages indicate levels relative to the 5 min time point. (B) RNA was fractionated on $2.4 \%$ agarose gels and then stained with SYBR Safe. A gel loaded with RNA from two biological replicates is shown. $M=$ double-stranded DNA size markers. (C-F) Levels of 23S, 16S and $5 S$ rRNA, and tRNA after rifampicin addition were quantified from three biological replicates. Nominal amounts of RNA were determined using the fluorescence of known quantities of the 500 and 1500 bp double-stranded DNA size markers as standards. The graphs show the average and standard deviation expressed as nanograms of RNA per $\mathrm{mL}$ of culture. Percentages indicate levels relative to the 2 min time point. 


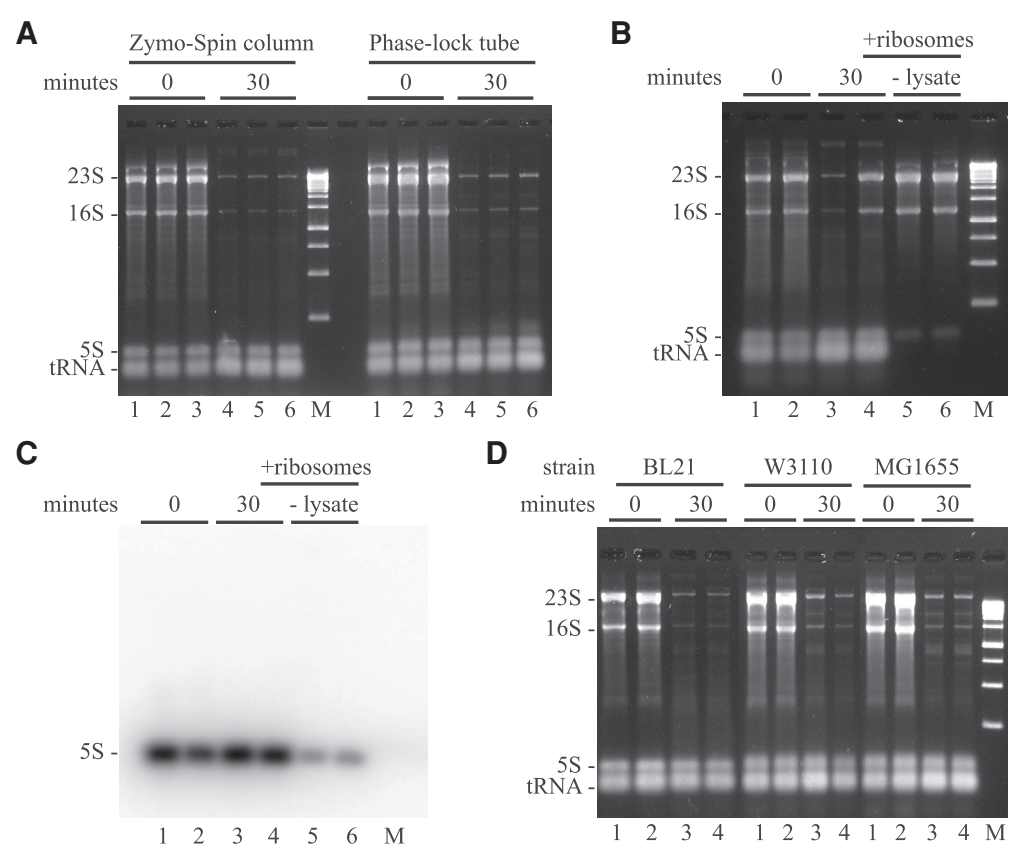

FIGURE 3. Rifampicin-induced degradation of $23 \mathrm{~S}$ and $16 \mathrm{~S}$ rRNA in E. coli K12 and B strains. Total RNA extracted from equal volumes of culture was separated by agarose gel electrophoresis. In $A, B$, and $D$, the gels were imaged by SYBR Safe staining. $M=D N A$ size markers. $(A)$ RNA was extracted by cell lysis in TRIzol and purification with either a Zymo-Spin column kit or Phase-lock fractionation and precipitation with isopropanol. Lanes 1-3, RNA extraction immediately after the addition of rifampicin (biological replicates). Lanes 4-6, corresponding RNA extraction 30 min after the addition of rifampicin. (B) RNA was extracted by cell lysis in TRIzol and purification with a Zymo-Spin column kit. Lanes 1 and 2, RNA extraction immediately after the addition of rifampicin (biological replicates). Lanes 3 and 4, corresponding RNA extraction $30 \mathrm{~min}$ after the addition of rifampicin. In lane 4, ribosomes were added to the cell extract before purification. In lanes 5 and 6, RNA was isolated from purified ribosomes (-lysate). (C) Northern blot of RNA from B probed with ${ }^{32} \mathrm{P}$-oligonucleotide specific to $5 \mathrm{~S}$ rRNA. (D) Rifampicin-induced rRNA degradation in BL21, W3110, and MG1655 strains of E. coli. Lanes 1 and 2, total RNA immediately after the addition of rifampicin (biological replicates). Lanes 3 and 4, corresponding RNA 30 min after the addition of rifampicin.

per $\mathrm{mL}$ of culture is equivalent in the biological replicates. Remarkably, total RNA levels drop 50\% between 5 and 15 min after the addition of rifampicin.

To characterize stable RNA species after rifampicin treatment, we separated total RNA by agarose gel electrophoresis, stained the gels with SYBR Safe and quantified the levels of 23S, 16S and 5S rRNA, and tRNA (Fig. 2B-F). The quantification shows the average and standard deviation from three biological replicates. There is a sharp 75\% decrease in the levels of $23 \mathrm{~S}$ and $16 \mathrm{~S}$ rRNA between 5 and $15 \mathrm{~min}$ after the addition of rifampicin. The levels continue to decrease with time resulting in an $\sim 90 \%$ decrease by 30 min. The data show that the percent decrease of $23 \mathrm{~S}$ and 16S rRNA is comparable, which is consistent with degradation of equimolar amounts of each species. In contrast, after an increase in 5S and tRNA levels during the first 10 min, which is likely due to the processing of precursors to their mature forms, these RNA species are stable.

The results in Figure 2B-F show that the loss of $23 \mathrm{~S}$ and $16 \mathrm{~S}$ rRNA contributes significantly to the $50 \%$ decrease in total RNA after the addition of rifampicin. Note that quantification of levels of total RNA, which is based on UV absorption, cannot be compared directly to nominal levels of individual RNA species, which is based on fluorescence intensities and normalization to known quantities of double-stranded DNA size markers.

Visual inspection of dozens of micrographs such as the ones shown in Figure 1 gave no indication of cell ghosting or lysis after rifampicin treatment. The conclusion that rifampicin does not disrupt cell integrity is supported by the stability of $5 \mathrm{~S}$ rRNA and tRNA after rifampicin addition (Fig. 2E,F). Since the RNA extraction protocol used here involves pelleting cells before lysis in TRIzol, this result argues strongly against the possibility that the decrease in $23 \mathrm{~S}$ and $16 \mathrm{~S}$ rRNA levels is due to loss of cell integrity and supports the conclusion that cell size reduction is due to terminal reductive cell division.

\section{Decrease in levels of 235 and $16 \mathrm{~S}$ rRNA is due to degradation in vivo}

We performed controls to test the possibility that our results are an artifact of the RNA extraction protocol. RNA was purified using either a Zymo RNA MiniPrep Plus kit or Phase-lock spin tubes and isopropanol precipitation. Figure $3 \mathrm{~A}$ shows that the decrease in $23 \mathrm{~S}$ and $16 \mathrm{~S}$ rRNA 30 min after the addition of rifampicin is the same using either protocol. As a further control, we added purified ribosomes to a TRIzol lysate of rifampicin treated cells (Fig. 3B, lane 4) and for comparison isolated RNA from an equivalent amount of purified ribosomes (Fig. 3B, lanes 5 and 6). Comparing lane 4 to lanes 5 and 6 shows that $23 \mathrm{~S}$ and 16S rRNA are fully recovered when the cell lysate (lane 4) was doped with purified ribosomes. These results show that the decrease in $23 \mathrm{~S}$ and $16 \mathrm{~S}$ rRNA levels is not due to loss or degradation during the extraction procedure. We therefore conclude that the reduction in levels of $23 \mathrm{~S}$ and $16 \mathrm{~S}$ rRNA after the addition of rifampicin is due to degradation in vivo.

The results in Figure 3B, lanes 1 and 2 vs. lanes 5 and 6 suggest that there is an excess of $5 \mathrm{~S}$ rRNA in vivo relative to $23 \mathrm{~S}$ and $16 \mathrm{~S}$ rRNA. The apparent overabundance of $5 \mathrm{~S}$ rRNA is highly reproducible when RNA is extracted by either of the methods used in Figure 3. We therefore northern blotted the RNA in Figure $3 \mathrm{~B}$ and probed it 

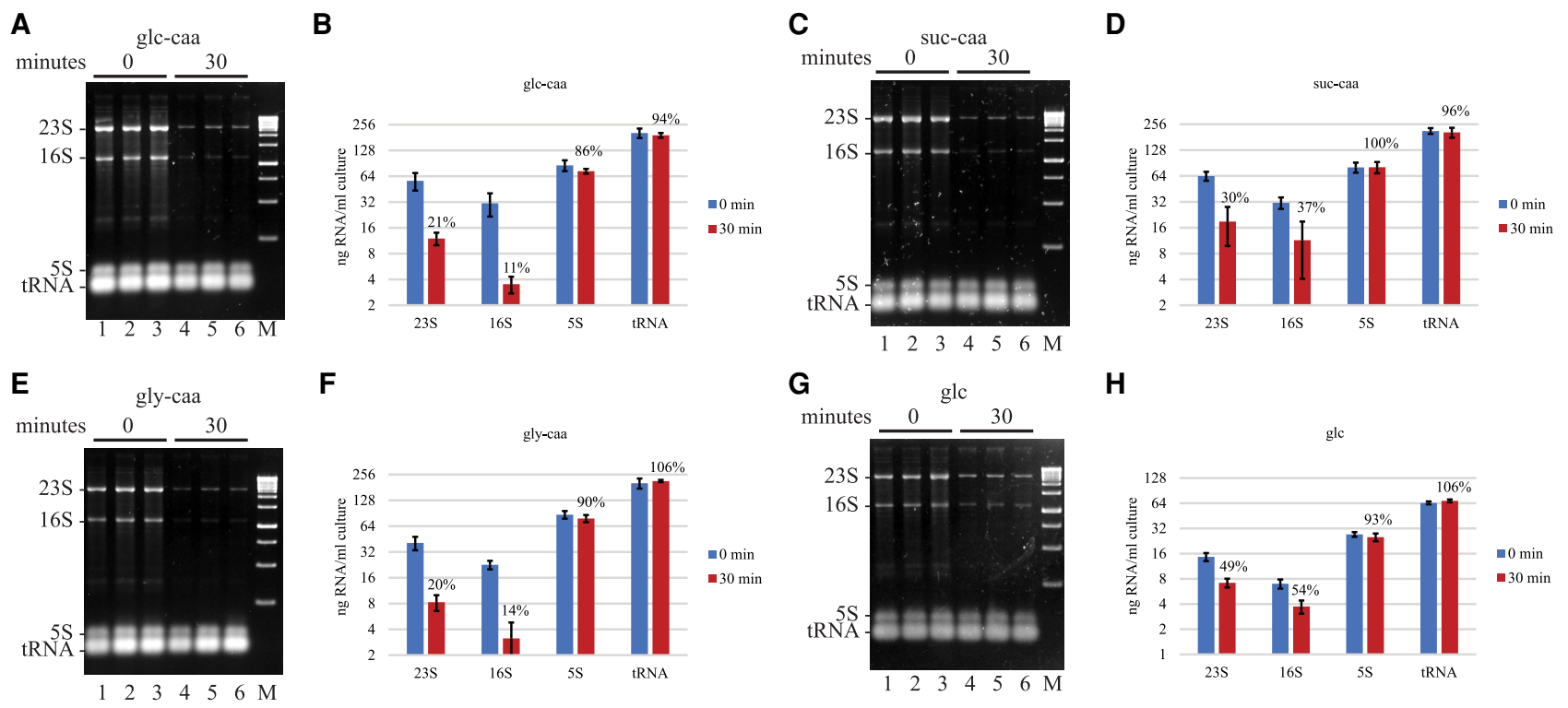

FIGURE 4. Rifampicin-induced rRNA degradation in MOPS media supplements with carbon sources and casamino acids. (A,C,E,G) SYBR Safe stained agarose gels. E. coli strain NCM3416 was grown in MOPS medium at $37^{\circ} \mathrm{C}$ supplemented with glucose (glc), succinate (suc) or glycerol (gly), and casamino acids (caa), except in G. Final concentration of carbon source and casamino acids was $0.5 \%$ and $0.2 \%$, respectively. Each gel shows three biological replicates. The 0 min time point was taken immediately after the addition of rifampicin. $(B, D, F, H)$ Levels of $23 S, 16 S$ and $5 S$ rRNA, and tRNA were quantified from six biological replicates. Nominal amounts of RNA were determined as described (Fig. 2). The graphs show the average and standard deviation expressed as nanogram of RNA per $\mathrm{mL}$ of culture. Percentages represent normalization of the 30 min time point after rifampicin addition to the 0 min time point.

with a ${ }^{32}$ P-oligonucleotide specific to 5S rRNA (Fig. 3C). The northern blot confirms that the species identified by SYBR Safe staining is indeed 5 S rRNA. The purified ribosomes used in Figure $3 \mathrm{~B}$ are a translationally active preparation purchased from New England Biolabs. Visual inspection of the rRNA in Figure 3B, lanes 5 and 6, suggests that the fluorescence intensities are as expected for a molar ratio of 1 molecule each per ribosome. We therefore conclude that there is more than 1 copy of $5 \mathrm{~S}$ rRNA per ribosome in vivo. This result was not investigated further.

\section{Rifampicin-induced degradation of rRNA in $E$. coli $B$ and $K 12$ strains}

We asked if rifampicin-induced rRNA degradation is characteristic of common laboratory strains of $E$. coli. BL21 and its derivatives are $E$. coli $B$ strains that are often used as hosts for the overexpression and purification of recombinant proteins. W3110 and MG1655 are E. coli K12 strains that have been extensively used in molecular genetics studies. Genome-wide sequence analyses have shown a 92\% overlap of coding sequences between the core $E$. coli $\mathrm{B}$ and K12 genomes (Studier et al. 2009). There is on average $\sim 1 \%$ single nucleotide polymorphisms (SNPs) in coding sequences although the SNPs are not uniformly distributed. NCM3416 is a wild-type K12 that has RNase PH activity $\left(r_{p h}^{+}\right)$. W3110 and MG1655 are rph ${ }^{-}$strains and deficient in the metabolism of some sugars and pyrimidine synthesis
(Jensen 1993; Soupene et al. 2003). Figure 3D shows that rRNA degradation is induced by rifampicin in BL21, W3110, and MG1655 at levels comparable to NCM3416 (Fig. 2). This result suggests that rifampicin-induced rRNA degradation is a common characteristic of E. coli strains.

\section{Rifampicin-induced rRNA degradation in MOPS media}

We asked if growth media affects rifampicin-induced rRNA degradation. In Figure 4A-F, MOPS media was supplemented with casamino acids (caa) and three different carbon sources: glucose (glc), succinate (suc) or glycerol (gly). In Figure 4G,H, growth was with glucose in the absence of casamino acids. Note that the levels of $23 \mathrm{~S}$ and 16S rRNA depend on growth media, which is consistent with higher ribosome content during faster growth. Under all conditions, there was a significant reduction in $23 \mathrm{~S}$ and 16S rRNA levels after rifampicin treatment whereas there was no difference in $5 \mathrm{~S}$ rRNA and tRNA levels. From these results, we conclude that rRNA degradation is induced by rifampicin at fast growth rates in rich medium (LB) as well as at slower growth rates in MOPS synthetic media.

\section{Cell survival after rifampicin treatment}

It is notable that $23 \mathrm{~S}$ and $16 \mathrm{~S}$ rRNA are never completely degraded after rifampicin treatment and that final levels 
of $23 \mathrm{~S}$ and $16 \mathrm{~S}$ rRNA are in the range of 5 to $10 \mathrm{ng} / \mathrm{mL} \mathrm{cul}$ ture (Figs. 2, 4). This result suggests that the maintenance of a low level of ribosomes could permit the reinitiation of protein synthesis, and thus cell growth, if the inhibition of transcription is relieved. To determine if rifampicin-treated cells can grow after removal of the antibiotic, we measured colony-forming units (cfu) as a function of time after the addition of rifampicin. Figure 5 shows a decrease to $46 \% \mathrm{cfu}$ $5 \mathrm{~min}$ after rifampicin addition followed by a recovery resulting in a level of $78 \%$ after $30 \mathrm{~min}$. Since there is a terminal cell division after the addition of rifampicin, the cfu level should increase to $200 \%$ by $30 \mathrm{~min}$. This result shows that some but not all cells can reinitiate growth after rifampicin treatment. The ability to grow after removal of rifampicin could depend on the number of ribosomes per cell that have escaped degradation (see Discussion).

\section{Effect of protein synthesis inhibitors on RNA levels}

One consequence of the inhibition of transcription by rifampicin is the inhibition of protein synthesis due to the depletion of mRNA. We therefore tested the effect of chloramphenicol and kasugamycin on stability of $23 \mathrm{~S}$ and $16 \mathrm{~S}$ rRNA. Figure 6 shows RNA profiles before and 30 min after addition of these inhibitors of protein synthesis. By visual inspection of gel images, we have consistently seen lower levels of $23 \mathrm{~S}$ and $16 \mathrm{~S}$ after chloramphenicol treatment. A decrease in $23 \mathrm{~S}$ rRNA is validated by the quantification in Figure 6B, but a decrease in 16S rRNA is not statistically significant. We believe that a background smear due to ongoing RNA synthesis interferes with accurate quantification of $16 \mathrm{~S}$ rRNA levels. Kasugamycin treatment resulted in an increase in 5S rRNA and tRNA levels showing that precursors of these species are processed to their mature form. Stability of the $23 \mathrm{~S}$ and $16 \mathrm{~S}$ rRNA suggests that rRNA is not degraded by kasugamycin treatment and that precursors of these species cannot be processed to their mature form. These results show that the

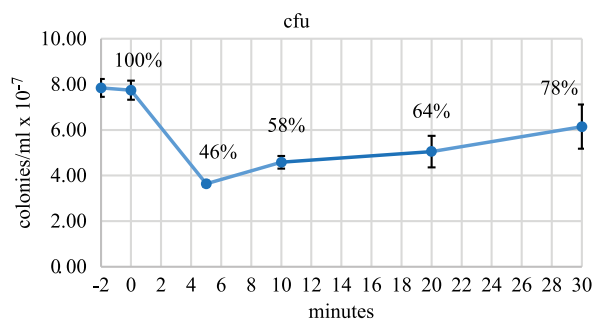

FIGURE 5. Colony forming units after treatment with rifampicin. Viable cells per $\mathrm{mL}$ of culture were measured by colony formation after serial dilution ( $10^{-6}$-fold) and plating on LB in the absence of antibiotic. Rifampicin was added at $0 \mathrm{~min}$. The graph shows the average and standard deviation of colony forming units (cfu) from three biological replicates. Percentages represent normalization to the -2 min time point. inhibition of protein synthesis is not a signal for $23 \mathrm{~S}$ and $16 \mathrm{~S}$ rRNA degradation. The result with kasugamycin was unexpected since this antibiotic inhibits translation initiation and we therefore expected that protective interactions between ribosomes and mRNA would be disrupted (see Discussion).

\section{Ribonucleases involved in rifampicin-induced rRNA degradation}

To identify the enzymes involved in the degradation of 23 and $16 \mathrm{~S}$ rRNA, we analyzed strains with mutations that inactivate genes involved in RNA processing and degradation. Figure $7 A, B$ show the result of rifampicin treatment of nine strains that are lacking activity of the following enzymes: RNase I, RNase II, RNase G, RNase R, RNase PH, poly(A)polymerase, PNPase, YbeY, and RNase III. Visual inspection of the gels shows that rRNA degradation is induced by rifampicin in each of these strains thus showing that these nucleases are not essential for rifampicin-induced rRNA degradation. However, as shown below, the pairwise inactivation of RNase R and PNPase reveals their role in the exonucleolytic degradation of rRNA. We therefore cannot exclude the possibility that double or triple mutations could uncover a role for enzymes such as RNase G, RNase III, or poly(A) polymerase.

mRNA interferases are encoded by many toxin-antitoxin (TA) elements in the E. coli genome. These enzymes inactivate mRNA by endoribonucleolytic cleavage. In principle, rifampicin treatment should induce mRNA interferase activity since the synthesis of anti-toxins, which are short-lived, is inhibited. We therefore tested the possibility that these endoribonucleases are involved in 23S and $16 \mathrm{~S}$ rRNA degradation. The $\triangle 10 T A$ strain was engineered to delete ten TA elements encoding mRNA interferases including MazF, RelB, HicA, HigB, and MqsR (Goormaghtigh et al. 2018). The gel in Figure 7C shows that rifampicin induces rRNA degradation in the $\triangle 10 T A$ strain thus suggesting that mRNA interferases encoded by these TA elements are not involved in rRNA degradation.

RNase R and PNPase have been implicated in rRNA quality control and rRNA degradation during starvation for a carbon source (Cheng and Deutscher 2003; Deutscher 2009; Zundel et al. 2009). These enzymes, which are major 3'-exoribonucleases in RNA turnover, have overlapping substrate specificities. Disruption of both genes encoding these enzymes is lethal. We therefore tested a temperature-sensitive strain that is defective for RNase $\mathrm{R}$ and PNPase activity at $42^{\circ} \mathrm{C}$. In Figure 7D, as expected, there is a large smear of low molecular weight RNA fragments in the 0 min time point due to the lack of 3 '-exoribonuclease activity. Thirty minutes after the addition of rifampicin, the levels of $23 \mathrm{~S}$ and $16 \mathrm{~S}$ rRNA decreased and the level of low molecular weight fragments increased. This result is 


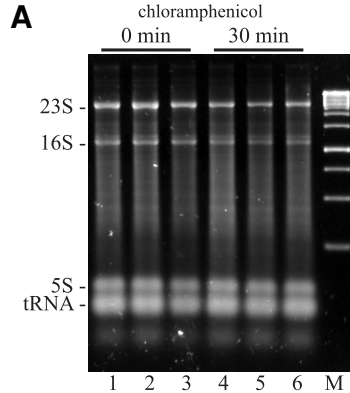

B

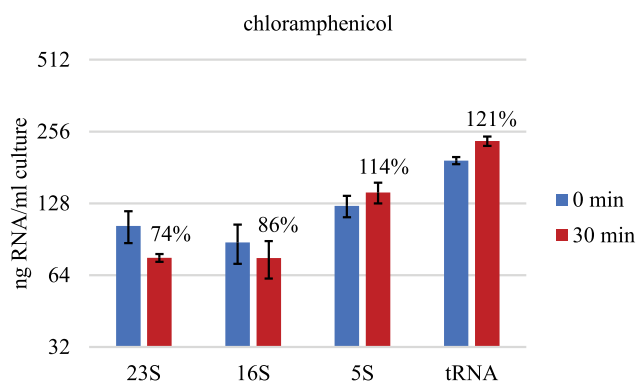

C

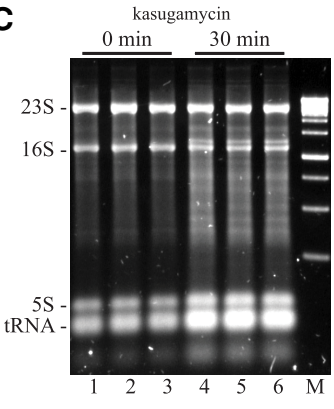

D

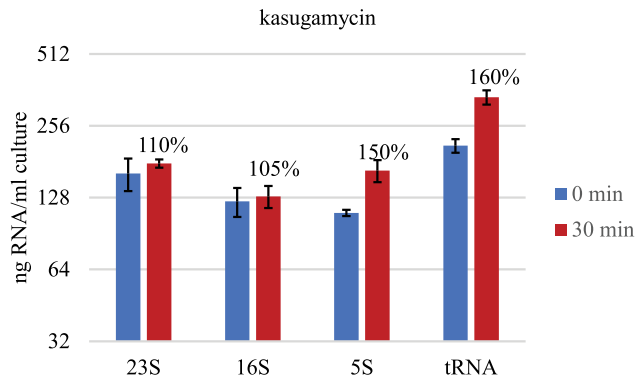

FIGURE 6. Effect of protein synthesis inhibitors on rRNA and tRNA levels. Total RNA extracted from equal volumes of culture was separated by agarose gel electrophoresis. The gels were imaged by SYBR Safe staining. $M=$ DNA size markers. $(A, C) N C M 3416$ grown in LB medium at $37^{\circ} \mathrm{C}$ was treated with chloramphenicol $(125 \mu \mathrm{g} / \mathrm{mL})$ or kasugamycin $(1 \mathrm{mg} / \mathrm{mL})$. The 0 min time points were taken immediately after addition of antibiotic. Lanes 1-3 are biological replicates; lanes $4-6$, the corresponding 30 min time points. $(B, D)$ Quantification of 23S, $16 \mathrm{~S}, 5 \mathrm{~S}$ rRNA, and tRNA levels showing the average and standard deviation from six biological replicates. Percentages represent normalization to the 0 min time point.

consistent with a pathway for rifampicin-induced rRNA degradation in which rRNA fragments are degraded by RNase $R$ and PNPase.

We next turned our attention to RNase $E$, an essential endoribonuclease in $E$. coli, that has been implicated in rRNA degradation upon starvation for carbon (Basturea et al. 2011; Sulthana et al. 2016). We tested two temperature-sensitive strains (AC22 and AC23) in which RNase $E$ is inactivated upon a shift from $30^{\circ} \mathrm{C}$ to $43.5^{\circ} \mathrm{C}$. AC21 is the wild-type control. Since mRNA degradation at the nonpermissive temperature is slowed but not abolished in these strains (Ono and Kuwano 1979; Babitzke and Kushner 1991), we performed the time courses shown in Figure 7E. The quantification in Figure 7F-I shows that there is no difference in 5S rRNA and tRNA levels after rifampicin addition. The apparent higher levels of $23 \mathrm{~S}$ and $16 \mathrm{~S}$ rRNA in the temperature-sensitive strains is due a background of undegraded RNA that accumulates after the shift to $43.5^{\circ} \mathrm{C}$. There is a clear lag in the degradation of $23 \mathrm{~S}$ and $16 \mathrm{~S}$ rRNA in the temperature-sensitive strains that is coherent with visual inspection of the gel in Figure 7E. We therefore conclude that RNase E cleavage is involved in rifampicin-induced degradation of rRNA.

The results in Figure 7 show that rifampicin-induced rRNA degradation involves the activities of RNase $E$,
PNPase and RNase R. The same pathway has been described for rRNA quality control and rRNA degradation upon carbon source starvation (Basturea et al. 2011; Sulthana et al. 2016). RNase $E$ is believed to initiate rRNA degradation by nicking inactive ribosomal subunits. However, our results raise the issue of whether RNase $E$ acts directly in rRNA degradation or indirectly since a slowdown of mRNA degradation in the temperature-sensitive strains results in a lag in the accumulation of inactive ribosomal subunits (see Discussion).

\section{DISCUSSION}

The arrest of growth by rifampicin is a potentially catastrophic event since inhibition of transcription prevents stress responses that require the synthesis of new RNA. For example, the entry of $E$. coli into stationary phase involves RpoS-dependent transcription and many stress responses require the induction of sRNA synthesis (Battesti et al. 2011; Hor et al. 2020). By imaging live cells on agarose pads and measuring their dimensions, we have shown a $50 \%$ reduction in cell size within 30 min of the addition of rifampicin, which is likely due to a terminal cell division. The initiation of chromosome replication is a tightly regulated and synchronized process that occurs once per cell division cycle (Skarstad and Katayama 2013). Drugs that inhibit transcription (rifampicin) and protein synthesis (chloramphenicol) block the initiation of chromosome replication. However, DNA synthesis is not inhibited and ongoing chromosome replication continues to completion. Since rapidly growing cells in rich medium divide faster than the time it takes to replicate a chromosome, there are more than two replication forks per cell. Due to completion of DNA replication, measurements showed that over $80 \%$ of cells had four chromosomes $90 \mathrm{~min}$ after the addition of rifampicin (Skarstad et al. 1986). Continued DNA replication due to the multifork nature of the bacterial chromosome has been postulated to be a mechanism for maintaining the rate of cell division after growth arrest (Zaritsky and Helmstetter 1992). The reduction in cell size together with the increase in chromosome copy number suggests significant remodeling of the cell with a large reduction in the ratio of cytoplasm to nucleoid (Gray et al. 2019). Indeed, single cell measurements have shown that the nucleoid fully occupies the interior of the cell after rifampicin treatment (Bakshi et al. 2014). Taken together, these results show that 
A single gene knockouts

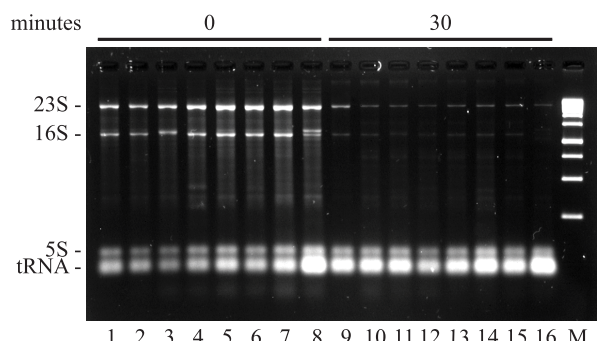

E

temperature-sensitive RNase $\mathrm{E}$

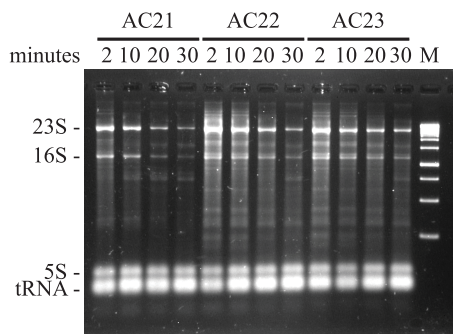

G

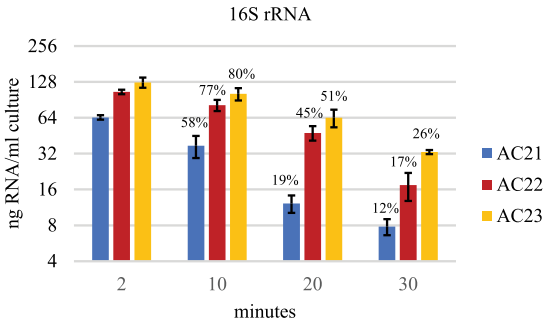

I

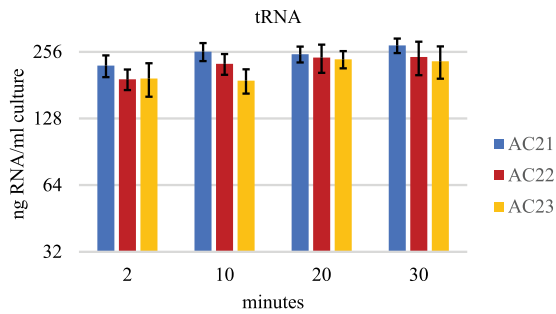

B RNase III

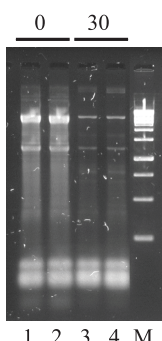

C TA elements

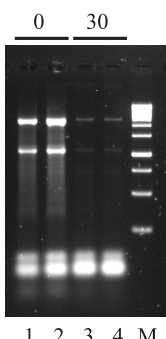

$\begin{array}{lllll}1 & 2 & 3 & 4 & \mathrm{M}\end{array}$

D 3'-exos

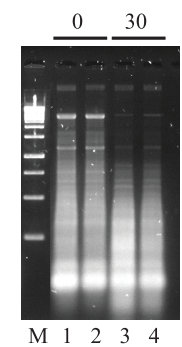

F

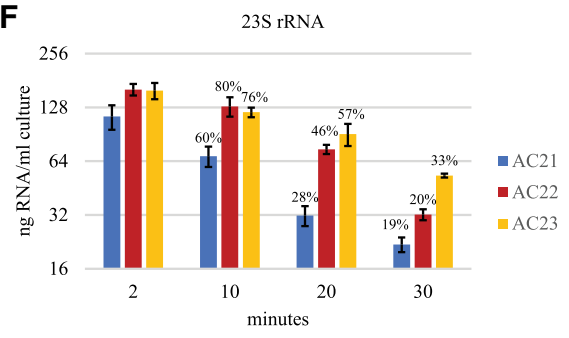

H

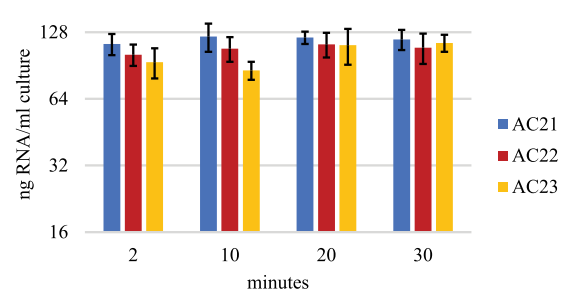

FIGURE 7. Ribonucleases involved in rifampicin-induced rRNA degradation. Total RNA extracted from equal volumes of culture was separated by agarose gel electrophoresis. The gels were imaged by SYBR Safe staining. $M=D N A$ size markers. In panels $A-D$, the 0 min time points were taken immediately after the addition of rifampicin $(150 \mu \mathrm{g} / \mathrm{mL})$. (A) Single gene knockouts. Lanes 1 to 8 correspond to mutant strains with gene deletions that result in the loss of the following proteins: RNase I, RNase II, RNase G, RNase R, RNase PH, poly(A)polymerase, PNPase and YbeY. (B) RNase III. Rifampicin treatment of the BL321 strain, which contains the rnc105 mutant allele resulting in a lack of RNase III activity (Portier et al. 1987). (C) TA elements. Rifampicin treatment of the $\Delta T A 10$ strain, in which ten toxin-antitoxin elements have been disrupted (Goormaghtigh et al. 2018). Each of these elements encodes an mRNA interferase that inactivates mRNA by endoribonucleolytic cleavage. (D) 3'-exos. Rifampicin treatment of the CA244 strain, which contains a knockout of the rnr gene encoding RNase R and the mutant pnp200 allele encoding a temperature-sensitive variant of PNPase (Cheng and Deutscher 2003). The strain was grown to $\mathrm{OD}_{600}=0.1$ at $30^{\circ} \mathrm{C}$ in $\mathrm{LB}$ and then shifted to $42^{\circ} \mathrm{C}$. Rifampicin was added $4 \mathrm{~h}$ after the temperature shift. (E) RNase E. AC21, AC22, and AC23 are isogenic strains containing the rne ${ }^{+}$, rne $(\mathrm{F} 68 \mathrm{~L})^{\text {ts }}$, and $\mathrm{rne}(\mathrm{G} 66 \mathrm{~S})^{\text {ts }}$ alleles, respectively (Carpousis et al. 1994). The strains were grown to $\mathrm{OD}_{600}=0.5$ at $30^{\circ} \mathrm{C}$ in $\mathrm{LB}$ and then shifted to $43.5^{\circ} \mathrm{C}$ for $10 \mathrm{~min}$ before the addition of rifampicin $(150 \mu \mathrm{g} / \mathrm{mL}$ ). RNA was extracted 2, 10, 20, and 30 min after the addition of rifampicin. ( $F-$ 1) Quantification of RNA levels. The bar graphs show the average and standard deviation of 23S, 16S, and 5S rRNA, and tRNA levels from three biological replicates performed as shown in E. AC21 is the isogenic wild-type control. AC22 and AC23 harbor mutant alleles encoding temperature-sensitive variants of RNase E. Percentages represent normalization to the 2 min time point.

rifampicin treatment resets the cell cycle to a resting state that preserves chromosome integrity. It is noteworthy that this reset occurs under conditions where transcription is blocked by rifampicin.
We have shown that there is a striking $50 \%$ decrease in total RNA after rifampicin treatment of cultures of E. coli in exponential growth phase. Electrophoretic separation of total RNA revealed a $90 \%$ decrease in $23 \mathrm{~S}$ and $16 \mathrm{~S}$ 
rRNA levels whereas 5S rRNA and tRNA levels were stable. We performed controls showing that the decrease in $23 \mathrm{~S}$ and $16 \mathrm{~S}$ rRNA is not an artifact of our RNA extraction protocol and therefore conclude that the decrease is due to degradation in vivo. We have observed rifampicin-dependent rRNA degradation in E. coli B and K12 strains as well as under different growth conditions. From these results we conclude that rifampicin-induced rRNA degradation is a general property of $E$. coli that occurs over a wide range of growth conditions and that does not depend on carbon source or amino acids. We suspect that nucleotides from rRNA degradation are recycled to deoxyribonucleotides for DNA synthesis. We estimate that the degradation of 2000 copies of $23 \mathrm{~S}$ and $16 \mathrm{~S}$ rRNA is sufficient for the synthesis of 1 chromosome. Ribosome content depends on growth rate. Considering measurements of absolute rates of synthesis of ribosomal proteins, we estimate that there are 140000 and 20000 ribosomes assembled per generation in MOPS complete and MOPS minimal medium, respectively ( $\mathrm{Li}$ et al. 2014). Degradation of $50 \%$ of $16 \mathrm{~S}$ and $23 \mathrm{~S}$ rRNA after rifampicin addition in MOPS complete and MOPS minimal medium would therefore liberate enough nucleotides to synthesize 35 and 5 chromosomes, respectively.

An overview of the data in Figures 2 and 4 shows that $23 \mathrm{~S}$ and $16 \mathrm{~S}$ rRNA degradation is never complete. Final levels are in the range of 5 to $10 \mathrm{ng} / \mathrm{mL}$ of culture, which is 10 fold lower than the levels in cells growing exponentially in rich medium. The results of cfu measurements in Figure 5, which show that $\sim 40 \%$ of cells 30 min after the addition of rifampicin can form colonies, suggest that a basal level of functional ribosomes contributes to the renewal of cell growth if the block in transcription is removed. The number of ribosomes per cell after rifampicin treatment could vary if rRNA degradation is a stochastic process. Single cell observations of the recovery of persister cells prepared by rifampicin treatment suggest a correlation between recovery and ribosome levels although quantification of ribosome levels involved an indirect method using a GFP reporter (Kim et al. 2018). If there is a correlation between ribosome levels and recovery from growth inhibition, then the capacity to form a colony after rifampicin treatment could depend on a threshold above which there are enough ribosomes to support cell growth.

Chloramphenicol treatment resulted in a small reduction of $23 \mathrm{~S}$ and $16 \mathrm{~S}$ rRNA levels. Since chloramphenicol inhibits translation elongation (Lambert 2012), this result suggests that ribosomes blocked on mRNA are at least partially protected from rRNA degradation. The continued synthesis of mRNA after chloramphenicol treatment could contribute to this protection. Kasugamycin treatment resulted in an increase in 5S rRNA and tRNA levels showing that precursors of these species can be processed to their mature forms in the presence of this antibiotic. There was no change in $23 \mathrm{~S}$ and $16 \mathrm{~S}$ rRNA levels. The apparent stability of $23 \mathrm{~S}$ and $16 \mathrm{~S}$
rRNA was unexpected since kasugamycin inhibits the initiation of translation of mRNA (Muller et al. 2016). We expected that the accumulation of inactive ribosomes due to the block in translation initiation would result in rRNA degradation. However, kasugamycin treatment modifies the ribosome resulting in a $61 \mathrm{~S}$ particle lacking a subset of $r$ proteins and the Shine-Delgarno binding site, which is removed by an RNase cleavage $43 \mathrm{nt}$ from the $3^{\prime}$ end of $16 \mathrm{~S}$ rRNA (Kaberdina et al. 2009; Muller et al. 2016). Leaderless mRNA produced by alternate transcription initiation and mRNA fragments produced by processing are translated by modified ribosomes, albeit at low levels. Our results suggest that modification of the ribosome and/or translation of leaderless mRNA protects $23 \mathrm{~S}$ and $16 \mathrm{~S}$ rRNA from degradation. An alternate but seemingly unlikely possibility is that mature $23 \mathrm{~S}$ and $16 \mathrm{~S}$ rRNA is degraded and then replaced by the processing of newly synthesized precursors to their mature form. Regardless of these considerations, the inhibition of translation and cell growth by chloramphenicol and kasugamycin does not provoke the massive decrease in 235 and 16 S rRNA levels that occurs after rifampicin treatment.

Ribosomal RNA is degraded under conditions such as glucose starvation. Considering experimental evidence, it was proposed that inactive 505 and 305 ribosomal subunits are nicked by RNase $E$ and that rRNA fragments are then degraded by PNPase and RNase R (Zundel et al. 2009; Basturea et al. 2011; Sulthana et al. 2016). There is precedent in the literature for rifampicin-induced rRNA degradation. Zundel et al. (2009) have shown that addition of rifampicin to cells starved for glucose increased rRNA degradation. A recent report has shown that starvation for carbon, amino acids or phosphate as well as rifampicin treatment results in the degradation of rRNA (Fessler et al. 2020). Our work shows that rRNA degradation is a direct consequence of the inhibition of transcription resulting in the degradation of mRNA and the accumulation of inactive ribosomal subunits.

We have tested a battery of mutant strains lacking or deficient in enzymes involved in RNA degradation as well as a strain in which 10 toxin-antitoxin (TA) elements encoding mRNA interferases were deleted. None of the single gene deletions or the deletion of the TA elements affected rifampicin-dependent rRNA degradation. Our results with temperature-sensitive mutant strains affecting the activities of RNase E, PNPase, and RNase R showed that these ribonucleases are involved in rRNA degradation. Rifampicin-induced rRNA degradation therefore follows the same pathway described previously for rRNA degradation during glucose starvation (Zundel et al. 2009; Basturea et al. 2011; Sulthana et al. 2016). Nevertheless, our kinetic analysis in Figure 7E and its quantification raises the issue of whether the effect of the RNase $E$ temperature-sensitive mutants is direct or indirect. Since the inactivation of RNase $E$ slows mRNA degradation, the lag in rRNA degradation could 
be due to a lag in the accumulation of inactive ribosomal subunits. Although not proof, we prefer the scenario in which RNase E acts directly in rRNA degradation since there is no evidence in Figure 7 that other endo-ribonucleases such as RNase G, RNase III, or TA encoded mRNA interferases are involved in rifampicin-induced rRNA degradation.

The work reported here has implications for protocols that use inhibition of transcription to measure rates of mRNA degradation. 5S rRNA, which is stable under the conditions reported here, has often been used as an internal standard to normalize transcript levels in northern blotting experiments. Whether there are other stable RNAs that can be reliably used as an internal standard is a question that should be explored. This is especially the case for genome-wide measurements of mRNA stability involving the synthesis of cDNA and high-density sequencing. The significant decrease in total RNA due to rifampicin-induced rRNA degradation reported here strongly suggests that normalizations assuming total RNA levels are constant will introduce a bias that results in an underestimation of mRNA degradation rates.

An equally important issue is that RNase E, PNPase, and RNase $\mathrm{R}$ are major enzymes in rifampicin-induced rRNA degradation as well as mRNA degradation (Deutscher 2006; Carpousis et al. 2009; Mackie 2013; Hui et al.
2014). Upon addition of rifampicin, the degradation of $23 \mathrm{~S}$ and $16 \mathrm{~S}$ rRNA, which are highly abundant, very likely competes with the degradation of mRNA and thus results in a slowdown in mRNA degradation. As we know of no way to measure degradation rates in genome wide studies without globally inhibiting mRNA synthesis, we believe that it will be necessary to model the effect of rRNA degradation on mRNA degradation rates and apply a correction that estimates degradation rates under normal growth conditions.

\section{MATERIALS AND METHODS}

\section{Culture medium, strains, and cfu measurements}

LB, MOPS media and agar plates (LA) were prepared as described (Miller 1972; Neidhardt et al. 1974). Glucose, glycerol or succinate $(0.5 \%)$ and casamino acids $(0.2 \%)$ were added to MOPS medium as indicated. Strains used in this work are listed in Table 1. Biological replicates were performed by inoculating an overnight culture with a single colony from a freshly streaked LA plate and then diluting the overnight culture $1 / 100$ and growing to $\mathrm{OD}_{600}=0.5$. RNA synthesis was inhibited with rifampin $(150 \mu \mathrm{g} /$ $\mathrm{mL})$. Protein synthesis was inhibited with chloramphenicol $(125 \mu \mathrm{g} / \mathrm{mL})$ or kasugamycin $(1 \mathrm{mg} / \mathrm{mL})$. To measure colony

TABLE 1. Strains

\begin{tabular}{|c|c|c|}
\hline Strain & Genotype & References \\
\hline NCM3416 & E. coli $\mathrm{K} 12, F^{-}, \lambda^{-}$, zib-207:: $\operatorname{Tn} 10$ & (Soupene et al. 2003) \\
\hline MG1655 & E. coli $\mathrm{K} 12, F^{-}, \lambda^{-}, \mathrm{rph}^{-}$ & (Jensen 1993) \\
\hline W3110 & E. coli K12, $\lambda^{-}$, IN(rrnD-rrnE)1, rph ${ }^{-}$ & (Jensen 1993) \\
\hline BL21 & E. coli $\mathrm{B}, \mathrm{F}^{-}$ompT gal dcm lon $h s d S_{B}\left(r_{B}^{-} m_{B}^{-}\right)\left[m_{a l B^{+}}\right]_{K-12}\left(\lambda^{S}\right)$ & (Studier et al. 2009) \\
\hline Kti162 & NCM3416, rne-mCherry & (Strahl et al. 2015) \\
\hline SLM001 & NCM3416, rne-mCherry, rpoB(D516Y) & This work \\
\hline SLM018 & NCM3416, pnp-msfGFP & To be described elsewhere \\
\hline SLM024 & NCM3416, rhlB-msfGFP & To be described elsewhere \\
\hline AC21 & MC1061, zce-726::TN10, rne ${ }^{+}$ & (Carpousis et al. 1994) \\
\hline AC22 & MC1061, zce-726::TN10, rne(L68F) ${ }^{\text {ts }}$ (aka rne3071) & (Carpousis et al. 1994) \\
\hline AC23 & MC1061, zce-726::TN10, rne(G66S) ${ }^{\text {ts }}$ (aka rne1) & (Carpousis et al. 1994) \\
\hline BL322 & thi-1, argH-1, supE44, rnc105 & (Portier et al. 1987) \\
\hline CA244 & (rna zbe-279::Tn10), pnp200 rnr::kan Cam ${ }^{r}$ & (Cheng and Deutscher 2003) \\
\hline$\Delta 10 T A$ & $\begin{array}{l}\text { MG1655, } \Delta \text { chpSB } \Delta \text { mazEF } \Delta \text { relBE } \Delta y e f M-y o e B ~ \Delta \text { dinJ-yafQ } \Delta \text { yafNO } \Delta \text { prlF-yhaV } \\
\text { } \Delta \text { hicAB } \Delta \text { higBA } \Delta \text { mqsRA }\end{array}$ & (Goormaghtigh et al. 2018) \\
\hline SLP40 & NCM3416, $\Delta y$ beY-FRT::Kan & This work \\
\hline JW0603 & BW25113, Arna-FRT::Kan & (Baba et al. 2006) \\
\hline JW1279 & BW25113, Arnb-FRT::Kan & (Baba et al. 2006) \\
\hline JW3216 & BW25113, Arng-FRT::Kan & (Baba et al. 2006) \\
\hline JW3618 & BW25113, Arph-FRT::Kan & (Baba et al. 2006) \\
\hline JW5741 & BW25113, Arnr-FRT::Kan & (Baba et al. 2006) \\
\hline JW5808 & BW25113, $\Delta p c n B-F R T:: K a n$ & (Baba et al. 2006) \\
\hline JW5851 & BW25113, Apnp-FRT::Kan & (Baba et al. 2006) \\
\hline
\end{tabular}


forming units after treatment with rifampicin, samples were serial diluted at room temperature in $\mathrm{BU}$ (per liter: $7 \mathrm{~g} \mathrm{NaH}_{2} \mathrm{PO}_{4} \cdot 2 \mathrm{H}_{2} \mathrm{O}$, $4 \mathrm{~g} \mathrm{NaCl}, 3 \mathrm{~g} \mathrm{KH}_{2} \mathrm{PO}_{4}$ ) and plated on LA.

\section{Measurement of cell dimensions}

Overnight cultures were diluted in $\mathrm{LB}$ to an $\mathrm{OD}_{600}=0.01$ and grown at $37^{\circ} \mathrm{C}$ with vigorous shaking to an $\mathrm{OD}_{600}=0.5$. Cells were imaged before and $30 \mathrm{~min}$ after adding rifampicin $(150 \mu \mathrm{g} / \mathrm{mL})$. Cells $(1-2 \mu \mathrm{L})$ were mounted on glass microscope slides with $1.2 \%(\mathrm{w} / \mathrm{v})$ agarose pads. Acquisitions were made with a Nikon Eclipse TI-E/B wide field epifluorescence microscope using a phase contrast objective (CFI Plan Fluor DLL $100 \times$ oil NA1.3). Images were captured immediately at room temperature and edited using Nis-Elements AR software (Nikon). Images were analyzed using ImageJ v.1.38 software (National Institutes of Health) (Collins 2007; Schneider et al. 2012). Line scans were drawn over the long and short axis of cells to produce phase-contrast intensity profiles. Sharp intensity changes occurred where the lines crossed the boundary between the interior and exterior of the cell. Cell length and width were calculated from the distance between the points where the intensity change was half maximum (FWMH method, full width at half maximum). Statistical significance of the differences between untreated and rifampicin treated cells was calculated using the nonparametric Mann-Whitney test (GraphPad Prism version 8.0).

\section{Construction of isogenic rifampicin resistant strain}

We obtained rifampicin resistant mutant strains by plating Kti162 on LA containing $200 \mu \mathrm{g} / \mathrm{mL}$ rifampicin. We selected a mutant strain for further characterization based on colony size and morphology comparable to the parent strain on LA plates at temperatures ranging from $20^{\circ} \mathrm{C}$ to $43^{\circ} \mathrm{C}$. DNA sequencing of the rpo $B$ gene encoding the $\beta$-subunit of RNA polymerase showed that a D516Y amino acid substitution is responsible for rifampicin resistance. The aspartate residue at position 516 makes a direct contact with rifampicin (Campbell et al. 2001; Alifano et al. 2015). The mutation was genetically "purified" by lambda RED recombineering using a $900 \mathrm{bp}$ DNA fragment from the rpoB coding region and then phage P1 transduction to construct the SLM001 strain. Since the phenotypic expression of rifampicin resistance requires growth to replace wild-type RNA polymerase with rifampicin resistant RNA polymerase, the P1 transduction protocol was modified by incubating phage transduced cells overnight before plating on rifampicin. In LB at $37^{\circ} \mathrm{C}, \mathrm{Kti} 162$ and SLM001 have equivalent doubling times ( $21 \mathrm{~min}$ ).

\section{Preparation of RNA, agarose gel electrophoresis, and northern blotting}

Samples $(5 \mathrm{~mL}$ ) were taken from $75 \mathrm{~mL}$ cultures and quenched with $1 \mathrm{~mL}$ of $5 \%$ phenol (in ethanol) at room temperature. Zero min time points were taken immediately after addition of rifampi$\operatorname{cin}(150 \mu \mathrm{g} / \mathrm{mL})$. After centrifugation ( $3000 \mathrm{~g}, 20 \mathrm{~min}, 4^{\circ} \mathrm{C}$ ), supernatants were decanted, residual liquid was removed with a Kimwipe, and cell pellets were stored at $-20^{\circ} \mathrm{C}$. Total RNA was extracted using a Direct-zol RNA MiniPrep Plus kit (Zymo
Research) as described (Hadjeras et al. 2019) except the DNase step was omitted. Briefly, cells were lysed under strongly denaturing conditions in TRIzol. RNA was column purified and eluted in $50 \mu \mathrm{L}$ of water. RNA amounts were quantitated by UV absorption using a Nano Drop spectrophotometer.

RNA was fractionated on mini format $2.4 \%$ agarose gels in $1 \times$ TBE at $100 \mathrm{~V}$ for $40 \mathrm{~min}$. Samples were either mixed directly with a $2 \times$ formamide loading buffer or dried in a SpeedVac and suspended in $1 \times$ formamide loading buffer. Before loading, samples were heated in a ThermoMixer $\left(50^{\circ} \mathrm{C}, 720 \mathrm{rpm}, 5 \mathrm{~min}\right)$. Gels were stained with SYBR Safe and imaged with a GelDoc system. Northern blotting was performed as described (Hadjeras et al. 2019).

rRNA and tRNA species were quantified using Image Lab software. In Figures 2, 4, 6 and 7, nominal amounts of RNA were determined using known quantities of the 750 and 1500 bp doublestranded DNA size markers as standards (1 kb ladder, ThermoScientific). In these figures, the quantification is presented as a $\log _{2}$ plot to better visualize RNA levels that vary as much as 50 -fold in some measurements.

\section{ACKNOWLEDGMENTS}

This work was supported by a grant from the Agence Nationale de la Recherche (IB-mRND, ANR-16-CE12-0014-02). We thank Jerome Rech for technical assistance on the Nikon microscope and Manual Campos, Laurence Girbal, Muriel CocaignBousquet, and Isabella Moll for helpful discussions and critical comments.

Received April 5, 2021; accepted June 3, 2021.

\section{REFERENCES}

Akerlund T, Nordstrom K, Bernander R. 1995. Analysis of cell size and DNA content in exponentially growing and stationary-phase batch cultures of Escherichia coli. J Bacteriol 177: 6791-6797. doi:10 .1128/jb.177.23.6791-6797.1995

Alifano P, Palumbo C, Pasanisi D, Tala A. 2015. Rifampicin-resistance, rpoB polymorphism and RNA polymerase genetic engineering. $J$ Biotechnol 202: 60-77. doi:10.1016/j.jbiotec.2014.11.024

Baba T, Ara T, Hasegawa M, Takai Y, Okumura Y, Baba M, Datsenko KA, Tomita M, Wanner BL, Mori H. 2006. Construction of Escherichia coli K-12 in-frame, single-gene knockout mutants: the Keio collection. Mol Syst Biol 2: 2006 0008. doi:10.1038/ msb4100050

Babitzke P, Kushner SR. 1991. The Ams (altered mRNA stability) protein and ribonuclease $E$ are encoded by the same structural gene of Escherichia coli. Proc Natl Acad Sci 88: 1-5. doi:10.1073/pnas 88.1.1

Bakshi S, Choi H, Mondal J, Weisshaar JC. 2014. Time-dependent effects of transcription- and translation-halting drugs on the spatial distributions of the Escherichia coli chromosome and ribosomes. Mol Microbiol 94: 871-887. doi:10.1111/mmi.12805

Basturea GN, Zundel MA, Deutscher MP. 2011. Degradation of ribosomal RNA during starvation: comparison to quality control during steady-state growth and a role for RNase PH. RNA 17: 338-345. doi:10.1261/rna.2448911

Battesti A, Majdalani N, Gottesman S. 2011. The RpoS-mediated general stress response in Escherichia coli. Annu Rev Microbiol 65: 189-213. doi:10.1146/annurev-micro-090110-102946 
Belasco JG. 2017. Ribonuclease E: chopping knife and sculpting tool. Mol Cell 65: 3-4. doi:10.1016/j.molcel.2016.12.015

Bernstein JA, Lin PH, Cohen SN, Lin-Chao S. 2004. Global analysis of Escherichia coli RNA degradosome function using DNA microarrays. Proc Natl Acad Sci 101: 2758-2763. doi:10.1073/pnas .0308747101

Burkhardt DH, Rouskin S, Zhang Y, Li GW, Weissman JS, Gross CA. 2017. Operon mRNAs are organized into ORF-centric structures that predict translation efficiency. Elife 6: e22037. doi:10.7554/ eLife.22037

Campbell EA, Korzheva N, Mustaev A, Murakami K, Nair S, Goldfarb A, Darst SA. 2001. Structural mechanism for rifampicin inhibition of bacterial RNA polymerase. Cell 104: 901-912. doi:10 .1016/S0092-8674(01)00286-0

Carpousis AJ, Van Houwe G, Ehretsmann C, Krisch HM. 1994. Copurification of E. coli RNAase E and PNPase: evidence for a specific association between two enzymes important in RNA processing and degradation. Cell 76: 889-900. doi:10.1016/0092-8674 (94)90363-8

Carpousis AJ, Vanzo NF, Raynal LC. 1999. mRNA degradation: a tale of poly(A) and multiprotein machines. Trends Genet 15: 24-28. doi:10.1016/S0168-9525(98)01627-8

Carpousis AJ, Luisi BF, McDowall KJ. 2009. Endonucleolytic initiation of mRNA decay in Escherichia coli. Prog Mol Biol Transl Sci 85: 91-135. doi:10.1016/S0079-6603(08)00803-9

Chao YJ, Li L, Girodat D, Forstner KU, Said N, Corcoran C, Smiga M, Papenfort K, Reinhardt R, Wieden HJ, et al. 2017. In vivo cleavage map illuminates the central role of RNase $\mathrm{E}$ in coding and non-coding RNA pathways. Mol Cell 65: 39-51. doi:10.1016/j.molcel.2016 .11 .002

Chen H, Shiroguchi K, Ge H, Xie XS. 2015. Genome-wide study of mRNA degradation and transcript elongation in Escherichia coli. Mol Syst Biol 11: 808. doi:10.15252/msb.20159000

Cheng ZF, Deutscher MP. 2003. Quality control of ribosomal RNA mediated by polynucleotide phosphorylase and RNase R. Proc Natl Acad Sci 100: 6388-6393. doi:10.1073/pnas.1231041100

Cheng ZF, Deutscher MP. 2005. An important role for RNase R in mRNA decay. Mol Cell 17: 313-318. doi:10.1016/j.molcel.2004 .11 .048

Collins TJ. 2007. ImageJ for microscopy. BioTechniques 43: 25-30. doi:10.2144/000112517

Dar D, Sorek R. 2018. Extensive reshaping of bacterial operons by programmed mRNA decay. PLoS Genet 14: e1007354. doi:10.1371/ journal.pgen.1007354

Deutscher MP. 2006. Degradation of RNA in bacteria: comparison of mRNA and stable RNA. Nucleic Acids Res 34: 659-666. doi:10 $.1093 / \mathrm{nar} / \mathrm{gkj} 472$

Deutscher MP. 2009. Maturation and degradation of ribosomal RNA in bacteria. Prog Mol Biol Transl Sci 85: 369-391. doi:10.1016/ S0079-6603(08)00809-X

Esquerre T, Laguerre S, Turlan C, Carpousis AJ, Girbal L, CocaignBousquet M. 2014. Dual role of transcription and transcript stability in the regulation of gene expression in Escherichia coli cells cultured on glucose at different growth rates. Nucleic Acids Res 42: 2460-2472. doi:10.1093/nar/gkt1150

Fessler M, Gummesson B, Charbon G, Svenningsen SL, Sorensen MA. 2020. Short-term kinetics of rRNA degradation in Escherichia coli upon starvation for carbon, amino acid or phosphate. Mol Microbiol 113: 951-963. doi:10.1111/mmi.14462

Goormaghtigh F, Fraikin N, Putrins M, Hallaert T, Hauryliuk V, GarciaPino A, Sjodin A, Kasvandik S, Udekwu K, Tenson T, et al. 2018. Reassessing the role of type II toxin-antitoxin systems in formation of Escherichia coli type II persister cells. MBio 9: e00640-18. doi:10 $.1128 / \mathrm{mBio} .00640-18$
Gray WT, Govers SK, Xiang Y, Parry BR, Campos M, Kim S, JacobsWagner C. 2019. Nucleoid size scaling and intracellular organization of translation across bacteria. Cell 177: 1632-1648.e1620. doi:10.1016/j.cell.2019.05.017

Hadjeras L, Poljak L, Bouvier M, Morin-Ogier Q, Canal I, CocaignBousquet M, Girbal L, Carpousis AJ. 2019. Detachment of the RNA degradosome from the inner membrane of Escherichia coli results in a global slowdown of mRNA degradation, proteolysis of RNase $E$ and increased turnover of ribosome-free transcripts. Mol Microbiol 111: 1715-1731. doi:10.1111/mmi.14248

Hor J, Matera G, Vogel J, Gottesman S, Storz G. 2020. Trans-acting small RNAs and their effects on gene expression in Escherichia coli and Salmonella enterica. EcoSal Plus 9 doi:10.1128/ecosalplus.ESP-0030-2019.

Hui MP, Foley PL, Belasco JG. 2014. Messenger RNA degradation in bacterial cells. Annu Rev Genet 48: 537-559. doi:10.1146/ annurev-genet-120213-092340

Jensen KF. 1993. The Escherichia coli K-12 "wild types" W3110 and MG1655 have an rph frameshift mutation that leads to pyrimidine starvation due to low pyrE expression levels. J Bacteriol 175: 3401-3407. doi:10.1128/jb.175.11.3401-3407.1993

Kaberdina AC, Szaflarski W, Nierhaus KH, Moll I. 2009. An unexpected type of ribosomes induced by kasugamycin: a look into ancestral times of protein synthesis? Mol Cell 33: 227-236. doi:10.1016/j .molcel.2008.12.014

Kim JS, Yamasaki R, Song S, Zhang W, Wood TK. 2018. Single cell observations show persister cells wake based on ribosome content. Environ Microbiol 20: 2085-2098. doi:10.1111/1462-2920.14093

Kimura S, Waldor MK. 2019. The RNA degradosome promotes tRNA quality control through clearance of hypomodified tRNA. Proc Natl Acad Sci 116: 1394-1403. doi:10.1073/pnas.1814130116

Laguerre S, Gonzalez I, Nouaille S, Moisan A, Villa-Vialaneix N, Gaspin C, Bouvier M, Carpousis AJ, Cocaign-Bousquet $M$, Girbal L. 2018. Large-scale measurement of mRNA degradation in Escherichia coli: to delay or not to delay. Methods Enzymol 612: 47-66. doi:10.1016/bs.mie.2018.07.003

Lambert T. 2012. Antibiotics that affect the ribosome. Rev Sci Tech 31: 57-64. doi:10.20506/rst.31.1.2095

Li GW, Burkhardt D, Gross C, Weissman JS. 2014. Quantifying absolute protein synthesis rates reveals principles underlying allocation of cellular resources. Cell 157: 624-635. doi:10.1016/j.cell.2014 .02 .033

Mackie GA. 2013. RNase E: at the interface of bacterial RNA processing and decay. Nat Rev Microbiol 11: 45-57. doi:10.1038/ nrmicro2930

Miao Z, Westhof E. 2017. RNA structure: advances and assessment of 3D structure prediction. Annu Rev Biophys 46: 483-503. doi:10 .1146/annurev-biophys-070816-034125

Miller JH. 1972. Experiments in molecular genetics. Cold Spring Harbor Laboratory, Cold Spring Harbor, NY.

Moffitt JR, Pandey S, Boettiger AN, Wang S, Zhuang X. 2016. Spatial organization shapes the turnover of a bacterial transcriptome. Elife 5: e13065. doi:10.7554/eLife.13065

Moore PB, Steitz TA. 2011. The roles of RNA in the synthesis of protein. Cold Spring Harb Perspect Biol 3: a003780. doi:10.1101/ cshperspect.a003780

Muller C, Sokol L, Vesper O, Sauert M, Moll I. 2016. Insights into the stress response triggered by kasugamycin in Escherichia coli. Antibiotics (Basel) 5: 19. doi:10.3390/antibiotics5020019

Neidhardt FC, Bloch PL, Smith DF. 1974. Culture medium for enterobacteria. J Bacteriol 119: 736-747. doi:10.1128/jb.119.3.736-747 .1974

Ono M, Kuwano M. 1979. A conditional lethal mutation in an Escherichia coli strain with a longer chemical lifetime of messenger 
RNA. J Mol Biol 129: 343-357. doi:10.1016/0022-2836(79) 90500-X

Perez-Ortin JE, Tordera V, Chavez S. 2019. Homeostasis in the central dogma of molecular biology: the importance of mRNA instability. RNA Biol 16: 1659-1666. doi:10.1080/15476286.2019.1655352

Portier C, Dondon L, Grunberg-Manago M, Regnier P. 1987. The first step in the functional inactivation of the Escherichia coli polynucleotide phosphorylase messenger is a ribonuclease III processing at the 5' end. EMBO J 6: 2165-2170. doi:10.1002/j.1460-2075.1987 .tb02484.x

Py B, Higgins CF, Krisch HM, Carpousis AJ. 1996. A DEAD-box RNA helicase in the Escherichia coli RNA degradosome. Nature 381: 169-172. doi:10.1038/381169a0

Schneider CA, Rasband WS, Eliceiri KW. 2012. NIH Image to Image J: 25 years of image analysis. Nat Methods 9: 671-675. doi:10.1038/ nmeth.2089

Skarstad K, Katayama T. 2013. Regulating DNA replication in bacteria. Cold Spring Harb Perspect Biol 5: a012922. doi:10.1101/cshper spect.a012922

Skarstad K, Boye E, Steen HB. 1986. Timing of initiation of chromosome replication in individual Escherichia coli cells. EMBO J 5: 1711-1717. doi:10.1002/j.1460-2075.1986.tb04415.x

Soupene E, van Heeswijk WC, Plumbridge J, Stewart V, Bertenthal D, Lee H, Prasad G, Paliy O, Charernnoppakul P, Kustu S. 2003. Physiological studies of Escherichia coli strain MG1655: growth defects and apparent cross-regulation of gene expression. J Bacteriol 185: 5611-5626. doi:10.1128/JB.185.18.5611-5626.2003
Strahl H, Turlan C, Khalid S, Bond PJ, Kebalo JM, Peyron P, Poljak L, Bouvier M, Hamoen L, Luisi BF, et al. 2015. Membrane recognition and dynamics of the RNA degradosome. PLoS Genet 11: e1004961. doi:10.1371/journal.pgen.1004961

Studier FW, Daegelen P, Lenski RE, Maslov S, Kim JF. 2009. Understanding the differences between genome sequences of Escherichia coli B strains REL606 and BL21(DE3) and comparison of the E. coli B and K-12 genomes. J Mol Biol 394: 653-680. doi:10.1016/j.jmb.2009.09.021

Sulthana S, Basturea GN, Deutscher MP. 2016. Elucidation of pathways of ribosomal RNA degradation: an essential role for RNase E. RNA 22: 1163-1171. doi:10.1261/rna.056275.116

Svenningsen SL, Kongstad M, Stenum TS, Munoz-Gomez AJ, Sorensen MA. 2017. Transfer RNA is highly unstable during early amino acid starvation in Escherichia coli. Nucleic Acids Res 45: 793-804. doi:10.1093/nar/gkw1169

Vanzo NF, Li YS, Py B, Blum E, Higgins CF, Raynal LC, Krisch HM, Carpousis AJ. 1998. Ribonuclease E organizes the protein interactions in the Escherichia coli RNA degradosome. Genes Dev 12: 2770-2781. doi:10.1101/gad.12.17.2770

Zaritsky A, Helmstetter CE. 1992. Rate maintenance of cell division in Escherichia coli $\mathrm{B} / \mathrm{r}$ : analysis of a simple nutritional shiftdown. J Bacteriol 174: 8152-8155. doi:10.1128/jb.174.24.81528155.1992

Zundel MA, Basturea GN, Deutscher MP. 2009. Initiation of ribosome degradation during starvation in Escherichia coli. RNA 15: 977983. doi:10.1261/rna.1381309 

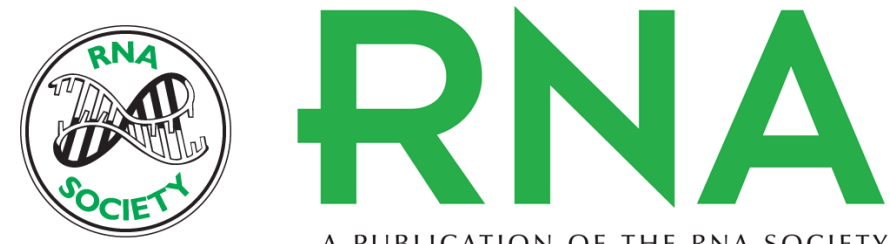

A PUBLICATION OF THE RNA SOCIETY

\section{Ribosomal RNA degradation induced by the bacterial RNA polymerase inhibitor rifampicin}

Lina Hamouche, Leonora Poljak and Agamemnon J. Carpousis

RNA 2021 27: 946-958 originally published online June 7, 2021

Access the most recent version at doi:10.1261/rna.078776.121

References This article cites 57 articles, 17 of which can be accessed free at: http://rnajournal.cshlp.org/content/27/8/946.full.html\#ref-list-1

Open Access Freely available online through the RNA Open Access option.

Creative This article, published in RNA, is available under a Creative Commons License

Commons (Attribution-NonCommercial 4.0 International), as described at

License http://creativecommons.org/licenses/by-nc/4.0/.

Email Alerting Receive free email alerts when new articles cite this article - sign up in the box at the Service top right corner of the article or click here. 